\title{
Correction to: Search-based multi-vulnerability testing of XML injections in web applications
}

\section{Sadeeq Jan ${ }^{1,2} \cdot$ Annibale Panichella ${ }^{1,3} \cdot$ Andrea Arcuri $^{4} \cdot$ Lionel Briand $^{1}$}

Published online: 7 June 2019

(C) The Author(s) 2019

\section{Correction to: Empirical Software Engineering https://doi.org/10.1007/s10664-019-09707-8}

The article Search-based multi-vulnerability testing of XML injections in web applications, written by Sadeeq Jan, Annibale Panichella, Andrea Arcuri, and Lionel Briand, was originally published electronically on the publisher's internet portal (currently SpringerLink) on May 2019 without open access.

With the author(s)' decision to opt for Open Choice the copyright of the article changed on June 2019 to (C) The Author(s) 2019 and the article is forthwith distributed under the terms of the Creative Commons Attribution 4.0 International License (http://creativecommons.org/licenses/by/4.0/), which permits use, duplication, adaptation, distribution and reproduction in any medium or format, as long as you give appropriate credit to the original author(s) and the source, provide a link to the Creative Commons license and indicate if changes were made.

The original article has been corrected.

Open Access This article is distributed under the terms of the Creative Commons Attribution 4.0 International License (http://creativecommons.org/licenses/by/4.0/), which permits use, duplication, adaptation, distribution and reproduction in any medium or format, as long as you give appropriate credit to the original author(s) and the source, provide a link to the Creative Commons license, and indicate if changes were made.

Publisher's note Springer Nature remains neutral with regard to jurisdictional claims in published maps and institutional affiliations.

The online version of the original article can be found at https://doi.org/10.1007/s10664-019-09707-8

Sadeeq Jan

jan@svv.lu

Annibale Panichella

a.panichella@tudelft.nl

Andrea Arcuri

andrea.arcuri@kristiania.no

Lionel Briand

briand@svv.lu

1 SnT, University of Luxembourg, Esch-sur-Alzette, Luxembourg

2 University of Engineering \& Technology, Peshawar, Pakistan

3 Delft University of Technology, Delft, Netherlands

4 Faculty of Technology, Kristiania University College, Oslo, Norway 